\title{
The Influence of Culture and Mentality on Retirement Planning in Kazakhstan
}

\author{
Aigerim Bakhtgalieva ${ }^{1^{*}}$, Madina Tasheva ${ }^{2}$, Benjamin Chan Yin-Fah ${ }^{3}$ \\ 1,2,3 Faculty of Business Management, Asia Pacific University of Technology \& Innovation (APU), Kuala Lumpur, MALAYSIA \\ ${ }^{3}$ Centre of Entrepreneuship and Leadership, (APU), Technology Park Malaysia, MALAYSIA \\ "E-mail for correspondence: bahtgalieva.aigerim@gmail.com
}

https://doi.org/10.18034/abr.v8i2.153

\begin{abstract}
The world is experiencing ageing phenomenal and the topic of individual retirement planning is becoming more important than before. Many studies focus on factors toward retirement planning, but limited researches studied how the culture and mentality influence the retirement planning in Kazakhstan country. This qualitative study has interviewed ten interviewees to explore how the culture and mentality concern contribute to their retirement planning decision. This paper entails the opinions and experiences about retirement planning among the younger generations in Kazakhstan.
\end{abstract}

Key words: Retirement planning, working adults, culture, mentality

\section{INTRODUCTION}

Retirement planning is important because people can be confident in their future and it satisfies them. Sustainability occurs when the pension program is working progressively, and each calculation helps a thorough retirement. People are concerned and use effective retirement strategies to secure their future and live the way they lived before retirement. Today, the world population is getting older, so the predictors towards retirement planning is becoming more crucial. This trend is mainly explored in Western countries, as well as in Japan, Australia Malaysia and Singapore (Chan et al., 2010; CSRI, 2016).

Kazakhstan introduced three levels of the pension system. The first level is a solidary and basic pension. A solidarity pension is accrued to persons who worked until 1998 for at least six months. The basic pension is received by everyone, for 2018 is 15,274 tenge (the National currency of Kazakhstan). The second level is a compulsory accumulative pension system with $10 \%$ pension tax. The third level is based on voluntary pension contributions. A full transition to the accumulative scheme will be completed in 2040 (Zhandildin, 2015).

Retirement planning also depends on the culture of each people. Depending on which culture, in which country this or that person grew, all this will affect his final decision. The research institute ING Retirement Research studies cultural influences, gender differences, the difference between generations, etc. The report "The Retirement Revealed" by ING U.S. it was revealed that each person has his own preferences, stories, and his own circumstances, which influence the adoption of certain decisions. Culture and heritage can influence investment and behavior in the pension investment market. Culture is characterized as a division of general and socially transmitted ideas about the world, which are passed on from generation to generation. Culture, as a social phenomenon, conveys the idea of people who interact all the time, they know the same unwritten principles and criteria of social life that give the status of a member of the group. Studies of national, cultural characteristics of peoples of different regions of the world today is one of the important factors in the study of various problems (Yusupova et al., 2014).

\section{RESEARCH QUESTION AND SIGNIFICANCE OF STUDY}

According to the above problem statement, the study seeks to examine the current mentality and culture in Kazakhstan, as well as how it affects retirement planning. The purpose of this study is to help the younger generation to understand how culture and mentality affect their retirement planning and give an opportunity to think about changing a certain mentality and culture for their future. An important factor for the people themselves is their recognition of the need to change culture and mentality. 


\section{LITERATURE REVIEW}

Kazakh peoples may have unique point of view about retirement planning due to different socioeconomic profile and geographical conditions in Kazakhstan. Nomadic life, boundless steppe open spaces, continental climate, the predominance of cattle-breeding farms has developed a certain shade in the way of thinking among Kazakh nation to be more openness, friendliness hospitality and so on.

For many centuries, the Kazakhs absorbed various cultural influences, remitting and assimilating them in the crucible of their native steppe Turkic traditions. And these traditions were so deep and strong that neither political catastrophes and wars, nor Arab and Mongolian influence, nor Islamization could change them radically. The specific mentality of the nation is formed throughout the whole history of its formation. The mentality of the nation is not only positive content but also negative. People, convinced of the conservatism and the absurdity of the individual elements of their mentality, can get rid of them. But this is a long historical process, covering a large period of time. In the Kazakhstan community, people knew each other well, the role of each of its members was clearly defined according to age and position. The norms of communication were known to everyone from childhood.

The similarity of interests, common views on life contributed to a rapid, conflict-free mutual understanding, interpersonal communication, and positive interpersonal relations. The community was cohesive, it cultivated customs and traditions of one kind or another. One of the distinctive features of Kazakhs is the special attitude to the younger generation. Living in difficult and harsh nomadic conditions, they, nevertheless, always found time and energy for caring for children. Women gave birth to as many children as the fate gave them, and they wanted to raise them worthy citizens of their land. Folk wisdom contains many statements about the Kazakhs' attitude to children and about the role of parents in their upbringing. Creating a family, the newlyweds understood that they would have to raise worthy heirs, who would be their support in old age and continue the traditions of their kind. In the treasury of folk wisdom reflected ethnopsychological attitudes, which indicated that children are the most important side of family happiness and well-being. "Whoever left his daughter behind him-left his tracks, who left his son-he himself remained." Thus, parental love was manifested in the care of children and the desire to raise worthy successors of a kind (Yegenisova and Erubaeva, 2015).

In Kazakhstan, the culture of an ancestor is still used. Together with modern worlds, it also combines old traditions. About Kazakhstan culture can be found in Kazakh literatures, which have been reporting since the
XV century and has a rich tradition. From the literary, philosophical works, which in one way or another reflect the features of the national mentality of the Kazakhs, it is first of all necessary to name "Words of edification" or "Book of Words" is a fundamental work of the Kazakh akyn and enlightener Abai Kunanbaev (1845-1905). In his book, the national mentality is presented "from within". Similarly, the author not only describes, summarizes the special traits of the character of his people. In the hope of improving the life of his people, he raises and impartial topics. Thus, the national character of the people appears most complete, multifaceted, and realistic. The description of the national mentality of Kazakhs "from the outside" - through the eyes of travelers and ethnographers since the 19th century, which refers to hospitality, tribal relations, the attitude of Kazakhs towards elders, women and children. Of course, in this situation, it can be explained by the fact that travelers focused more on the topic of the attitude of the local population towards themselves than on an in-depth study of the peculiarities of the relationship between the indigenous people among themselves (Lamajaa, 2013).

In the article by Mukhtarova G. "Japan and Kazakhstan: the dialogue of traditional cultures" it was written: "Having penetrated into the psychological causes of such phenomena, it should be noted that for both peoples the veneration of the family was very valuable. The family here is represented as a system of cohesive social values (Mukhtarova, 2002). This was the ideological concept of "Nation - Family". And an unknown author, a member of the Internet newspaper ZONAKZ, who wrote an article "The Kazakh mentality is the path to nowhere" emotionally declares: "In the sphere of interests of the Kazakhs only he, his wife, children, close relatives are included. Here for them he will kill himself and be crushed to the nines. Will go to any action that would be good for them. Even if their actions go against public morality, morality and even the laws of the Republic Kazakhstan, the Kazakh will still stand on the side of his relatives and friends".

In Yavorska's work, it was concluded that, firstly, the mentality of the Kazakh people has become rooted in a reverent attitude to the family and family relations, and they will never give up this value. Secondly, Kazakhs from ancient times managed to manage their relatives, to use familiarity for the good of the cause. This means that it is $100 \%$ realistic to be able to manage a modern company as efficiently as possible, accurately determining the abilities of relatives, using their fidelity to traditions, love and attachment to the family. Also, because of the mentality, the negative qualities of the Kazakh people were revealed, such as a waste of money, fear of not being accepted in one's family, dependence on someone else's opinion, cunning, the involvement of employees in the work of family ties, hope for support of relatives, and immediately, corruption, etc. At the same time, $88 \%$ of the positive response was 
about the family business, which means that Kazakh families hire relatives, even though relatives do not know how to work. Globally, the family nature of Kazakh business is manifested in the phenomena of corruption, low development and economic decline. In terms of wages, too, serious shortcomings were identified. Salaries usually do not depend on the professional abilities of family members, the company's directors do not always accurately withstand the timing of the issuance of wages, uneven bonuses are distributed, which leads to the demotivation of non-professional employees and high staff turnover. The author concluded that the mentality will always influence all spheres of life of Kazakhs and any other ethnos.

\section{Methodology}

The research employed qualitative and interpretivism philosophy. Data will be primary which will be obtained from the interview. The answers will be collected from different companies in Kazakhstan, where adults work at the age of 35 to 63 years. Data collection will be a semistructured individual in-depth interview with a size of ten targeted samples. This kind of interview is open-ended interview questions. Interviews will be recorded on the recorder to ensure genuine analysis. Anonymity is highly valued in this study because a few key ethical considerations concern the confidentiality of possible and actual participants in the voluntary nature of participation and the right to partially or completely abandon the process. Interview conversations will be translated and be categorized in the codes. The number of codes will depend on the information in the interview. After that, a report will be created, and the results presented (Bengtsson, 2016).

\section{Research Result}

Majority of respondents answered that they are financially rely on their children, but few cases reported that they are financially independent. One of them explained that "Now I have two daughters, I try to invest in their knowledge and I hope for their help in the future. If they cannot help me, then I will live on my pension or find another option, for example, work after retirement and start a business".

According to traditions in every Kazakh family, children are taught to respect for elders since young as the highest, most important principle. Each child hears these words: "The word of the elder is honey", "As you thank your father, so will your children thank you", etc. In addition, since birth parents say that children should take care of their parents at retirement age, and cares about his children until the children will not be able to take care of themselves. Also, in each house, the younger son must stay with his parents and help them in their old age. These traditions are still being practice till now. The younger son will not simply leave the parents if the parents do not decide to live separately while other siblings will always help their parents. If the family does not have a son, then parents will choose to be staying alone because according to the traditions of Kazakhstan, the daughter is considered a guest in the house before her marriage. If take history, Kazakhstan was divided into tribes. And the marriage was forbidden until the seventh generation. Therefore, the daughters married men from another tribe and went to live in another village. It is believed that the girl after the marriage will belong to another family. Even now, girls are perceived as guests at home and know that sooner or later they will leave their parents' house after marriage. But in the modern world, there are exceptions, when the daughters stay with their parents or help them at retirement age with their husband. As quoted from one of the interview responses "I rely on my 4 sons who will help me in my old age, but also, I rely on myself. Also, it is accepted, that the younger son remains at home and will look after parents. This is our mentality".

Two of them explained that "The people of Kazakhstan are very much paying attention to an extraneous opinion" and "Our mentality is, on the one hand, good, but also bad. We do not abandon children or a pensioner, but in the same way, but we teach children to depend on us and after that, they cannot live separately. Kazakhs are dependent on someone else's opinion, this is another reason that children cannot leave their parents". So that means, from ancient times, for children who leave their parents without help is a great disgrace.

In any situation, people of Kazakhstan will first choose their family. In any situation, people of Kazakhstan will first choose their family. One of the respondents had this to say, "I must help the children get on their feet. Feed the whole family. Also, help my parents who are already in retirement. I feel a great responsibility to them". In this way, parents cannot leave their child after adulthood, as in other countries, and children cannot leave their parents in retirement age without help. In Kazakhstan, parents, despite everything, will try to give knowledge to their child, they will pay for their studies and will help with money until children themselves earns a stable income. They will also provide their parents for the rest of their lives, helping them financially and morally.

The interview showed that residents of Kazakhstan planned to accumulate money, only in the short term.

In Kazakhstan, it turned out that each family should have its own house. The result showed that in the short term, Kazakhstan people save money for buying or building a house, buying a car, as well as educating children.

Similarly, the influence of the mentality of the Kazakhs on building personnel is also important. Another reason is the influence of the Kazakh mentality on the building of cadres. As quoted by the respondents, "In Kazakhstan it is a little difficult to find a job if there is no connection with relatives. It's also difficult to climb the career ladder". So, because of the hiring of relatives, those who do not have any connections are very difficult to find a job. 
At the end of the interview, respondents were introduced for nursing home concept. Thus, according to the answer of one of their respondents, "Other country might have different mentality, but I would not want to change our mentality", can say that the inhabitants of Kazakhstan do not want to change their mentality.

Summarizing can say that the Kazakhs have dependence on children in retirement age. They did not deal with the retirement planning and do not want to start yet because the citizens of Kazakhstan have concerns for the present day. Adults take care of their parents and many help their brothers and sisters in material terms, just as if they have children, they pay all the education fee that their children will receive. And in addition, they will take responsibility until the children find a job and earn a stable income. Thus, because of these costs, they do not have extra money left to save. For them, investing in the knowledge of their children is considered compulsory.

Given the history, for Kazakhstan it was considered a disgrace to leave the family to the mercy of fate, therefore, to this day, citizens of Kazakhstan consider social opinion and children cannot leave their parents without their help and parents will not leave their children. In addition, if there is no connection, then finding work is difficult or the salary will be low, which also does not allow people to think about retirement planning.

Thus, most people living in Kazakhstan do not have extra money for retirement savings and many spend money on the need in the present. In addition, giving the opportunity to choose the answerers between the independent retirement life without a family with a high pension and dependent on the family with a small pension, an answer was received that everyone will choose a family even if they live poorly. So, because of the historical background, care for the family and social opinion, people living in Kazakhstan do not plan their retirement in advance.

\section{CONCLUSION}

The results of the study, it was clarified that parents in Kazakhstan never abandon their parents and children to their fate. They will take care of their parents as retirees and provide their children until the children can provide for themselves and no matter what age children will be. People living in Kazakhstan will always prefer to live "poorly" with the family, than "richly" without a family. Due to the fact that citizens of Kazakhstan have a fear of being discussed and condemned by strangers, which also prevents them from not taking care of the family. In addition, if there are no acquaintances in any job, then getting a good job and get a promotion on the career ladder is very difficult, which also leads to the fact that it is very difficult to accumulate a good pension.

\section{ACKNOWLEDGEMENTS}

I want to express my appreciation to Aigerim Bakhtgalieva and Madina Tasheva in converting part of the term paper into this paper. Knowing that there are rooms of improvement in this paper but their first attempt in publication should be given supports and encourages.

\section{REFERENCE}

Bengtsson, M., (2016). How to plan and perform a qualitative study using content analysis. NursingPlus Open, 2, pp.8-14.

Chan, BYF, Tengku-Aizan, H., Masud, J., Paim, L (2010) Predictors of financial dependency in old age in Peninsular Malaysia: an ethnicity comparison. Asian Social Science, 6 (6). pp. 54-62.

CSRI, (2016). Sustainable Retirement Income Integrated Reform Programme.

Lamajaa, C.K., (2013) On the national character of the peoples of Central Asia. Knowledge. Understanding. (3), pp.99-108. (In Russian)

Mukhtarova G.S., (2002). Japan and Kazakhstan: a dialogue of traditional cultures. Modern art of Kazakhstan: problems and searches // Collected papers KAZNAI them. T. Zhurgenova. - Almaty. pp. 224 - 227. (In Russian)

The "Retirement Revealed" study from ING U.S. http:/ /diversityinc.com/medialib/uploads/2012/02/Reti rement-Revealed-White-Paper.pdf

Yavorska Z.H., The influence of the Kazakh mentality on building human resource management in Kazakhstan. (In Russian)

Yegenisova, A.K. and Erubaeva A.R., (2015). Psychological features of the national mentality of the Kazakh people. International Journal of Experimental Education. (4-2), pp.371-376. (In Russian)

Yusupova, A.S., Galiullina, G.R. and Denmukhametova, E.N., (2014). Representation of national mentality in Turkic-Tatar vocabulary. Life Science Journal, 11(7), pp.506-508. available at: https://kpfu.ru/staff_files/F1667594245/jusupova.pdf

Zhandildin, M., (2015). Pension System Reform in Emerging Countries: The Case of Kazakhstan. Global Journal of Emerging Market Economies, 7(1), pp.65-88.

$--0--$ 